\title{
Refractory Enteropathy-Associated T-Cell Lymphoma
}

National Cancer Institute

\section{Source}

National Cancer Institute. Refractory Enteropathy-Associated T-Cell Lymphoma. NCI

Thesaurus. Code C8681.

Enteropathy-associated T-cell lymphoma that is resistant to treatment. 